\title{
Monitoring of Metal Deposition by Moss Barbula Constricta J. Linn., from Mussoorie Hills in the India
}

\author{
Kajal Srivastava ${ }^{1}$, Shivom Singh ${ }^{2}$ and Dinesh Kumar Saxena ${ }^{3}$ \\ ${ }^{I}$ G.B. Pant University of Agriculture \& Technology, Department of Biological Sciences \\ ${ }^{2}$ ITM University, Department of Environmental Sciences and Technology \\ ${ }^{3}$ Bareilly College, Department of Botany
}

crossref http://dx.doi.org/10.5755/j01.erem.67.1.1750

(Received in October, 2013; accepted in March, 2014)

\begin{abstract}
The moss Barbula constricta J. Linn. was used as an active bio-monitor for estimation of atmospheric metal deposition and its seasonal trend to assess the metal $(\mathrm{Zn}, \mathrm{Pb}, \mathrm{Cu}, \mathrm{Cd})$ status of Mussoorie city and its adjoining areas. Moss transplants were exposed for four months, each period representing winter, summer and monsoon season data at the distances of $0.5,1.0$ and $3.0 \mathrm{~km}$ during 2003 to 2007 .

Significantly higher levels of $\mathrm{Zn}, \mathrm{Pb}$, and $\mathrm{Cu}$ were measured in the moss harvested at the end of each season. The values of metals at different distances from the city center were higher than in the background samples treated as control. Patterns of moss analysis for seasonal and annual metal data were closely identical. Values of metals were the highest during summer followed by winter, and the lowest in monsoon. It was found that an increase recorded in the sampling sites in the past 5 years could be due to the rapid economic development and the manifold increase in tourist activities. Results from the present moss surveys make the examination of both spatial and temporal trends of metals possible, and also confirm the validity of moss B. constricta J. Linn. as a reliable bio-monitor, and recommend it for the bio-mapping program. Data from existing surveys of metal concentrations in moss is filling a gap due to very limited information available in this field. In addition, it is an invaluable resource for policy makers in preparing the strategies for mitigation.
\end{abstract}

Keywords: Barbula constricta, bio-monitoring, metal load, DMRT.

\section{Introduction}

Assessment of environmental metal pollutants and the menace they pose to the whole ecosystem have been a vital challenge to the environmental sciences. Bio-indication and bio-monitoring of metals by moss have proven to be excellent and cheap ways to observe impacts of external factors (Markert et al., 2003). Bryophytes, due to their morphological and physiological constitution, are indispensable tools within the field of monitoring air pollution, as they lack a true root system, thus the intake of water, nutrients, and consequently also toxic substances occurs predominantly via atmospheric deposition (Genoni, 2000; Carballeira \& Fernandez, 2002; Culicov et al., 2002) through the outer surface. Their reaction to changes in the environment is quick and more direct than that of the majority of vascular plants due to their thick and waxy cuticle. The suitability of mosses to monitor atmospheric deposition has been recognized since the early investigations in northern Europe (Ruhling \& Tyler, 1968; 1973).

An advantage of moss lies in its no need of expensive equipment. High element concentrations in mosses lead to simpler analyses, fewer contamination problems, and the results give an integrated exposure over years (Figueira et al., 2002; Schilling \&Lehman, Aceto et al., 2003; Poikolainen et al., 2004). On the other hand, they are strongly resistant to numerous toxic substances and are even accumulating them (heavy metals and a wide range of persistent organic pollutants). Due to uptake mechanisms of these substances, a correlation between input and concentration is permitted and determination of the 
exact period of deposition is possible. They have been proved to be excellent accumulation indicators in many studies (Saxena et al., 2008). Moss bags are a reliable and effective method for determining total levels of atmospheric metal pollutants even in big areas (Ceburnis \& Valiulis, 1999; Fernandez et al., 2000; Couto, 2004; Špirić et al., 2013).

The focus of present work is on validation of $B$. constricta J. Linn. as a bio-monitor of atmospheric metal deposition at different sites in the Mussoorie district of the Garhwal hills (Figures 1-5). Moss $B$. constricta J. Linn. has been chosen, as it is easily identifiable and has a wide range in distribution (Saxena et al., 2007) for evaluating deposition patterns of $\mathrm{Cd}, \mathrm{Cu}, \mathrm{Pb}$, and $\mathrm{Zn}$. The suitability of this moss species as a bio-monitor of atmospheric metal deposition was evaluated by comparing the results with a bulk deposition of elements in the same moss area. The primary purpose of bio-monitoring studies is to establish a baseline of data, so that trends can be identified over time.

\section{Methods}

\subsection{Study area}

Musoorie city is located in the Garhwal hills at an altitude of 2005.5 meters covering the area of $6.425 \mathrm{sq}$. km. The study area is renowned for its congenial atmosphere that helps revive ailing visitors and remains overcrowded throughout the year due to increasing tourist activity. Moreover, secondary sources of pollution are transportation routes, domestic waste landfills, windblown metal load, and agricultural activities. The study area is mostly hills, bounded towards east by the dense forest cover of Chamba having an altitude of 1524 meters, considered as a control site. The climate is sub-arid, with maximum rainfall averaging about $702 \mathrm{~mm}$ from July to October. High relative humidity was measured during July and August at about $90 \%$; whereas it was minimal in January $(60 \%)$.

\subsection{Designing of samples for mapping}

Samples of Barbula constricta J. Linn. were collected during three different seasons of the period of 2003 to 2007 in accordance with the Indian weather conditions (summer, winter and monsoon). Transplantations of fresh moss were done at equidistances of $0.5,1$ and $3 \mathrm{~km}$ on 12 stations (direction wise) within the study area nearly at the same height. Samples were also taken from the interior of the Chamba forest cover (considered as a control site for base line concentration). Sampling of healthy moss and its handling were carried out using plastic gloves and bags.

$6 \mathrm{~g}$ of fresh moss was placed into a loosely knitted nylon moss bag of $20 \mathrm{~cm}^{2}$ size only one day before the transplantation. Moss bags were transplanted to different sampling points in triplicate, nearly at an equal height i.e. about 12 feet (away from the buildings). After the end of the exposure period of one season (nearly after 122 days or 4 months), these moss transplants were harvested and moss sample was taken from each transplant bag for the metal analysis, whereas in its place fresh moss (in triplicate) was transplanted for the same duration for the next season (four months). The same process was repeated for every season during five consecutive years.

\subsection{Sample treatment and chemical analysis}

Harvested moss samples were kept in plastic bags and were brought to the laboratory. Unwashed samples were carefully freed from dead material and attached litter. A jet of air was used to remove soil particles trapped in the moss. The apexes of green moss shoots $(1-2 \mathrm{~cm})$ were dried for $48 \mathrm{~h}$ at about $40^{\circ} \mathrm{C}$ in air-oven, and the samples were then homogenized. For the analysis, $0.5 \mathrm{~g}$ of homogenized moss tissue was digested $4: 1 \mathrm{v} / \mathrm{v}$ using $\mathrm{HNO}_{3}$ and $\mathrm{HClO}_{4}$ at $120^{\circ} \mathrm{C}$. Digests were analyzed for $\mathrm{Cd}, \mathrm{Cu}$, $\mathrm{Pb}$, and $\mathrm{Zn}$ by Atomic Absorption Spectrophotometer. Plant metal concentrations were expressed on a total dry weight basis.

\subsection{Statistical analysis and distribution maps}

The statistical evaluation of complete data was done and all analyses were performed based on triplicate moss transplants of five consecutive years. Data were subjected to one-way analysis of variance (ANOVA) with differences in the metal concentration in different seasons (JMP 5.0, SAS Institute, Cary, NC, USA) to analyze the effect of each treatment separately. The treatment means were separated using Tukey HSD at $0.05 \%$ probability level.

\section{Results and Discussion}

The metal concentration data of each season is summarized in Table 1. Figures 1, A to E, show the results where the annual average of metal loads of each element belongs to five consecutive years. The averages of $\mathrm{Zn}, \mathrm{Pb}$, and $\mathrm{Cu}$ concentrations in the transplanted moss were significantly higher than those from the background control site, while, the concentration of $\mathrm{Cd}$ was only slightly increased. However, from 2003 to $2005 \mathrm{Cd}$ was measured below the detection limit (ND) in a baseline (control site). Data revealed that seasonal accumulation of metals $(\mathrm{Zn}, \mathrm{Pb}, \mathrm{Cu}$, and $\mathrm{Cd})$ in B. constricta J. Linn. was in the order of summer $>$ winter $>$ monsoon in each year (Table 1). Nevertheless, the reason for highly significant seasonal trend could be due to the peak consumption of gasoline during summer due to many folds increased tourist activity and also due to decrease in moss growth during dry summer period (Gerdol et al., 2000). However, in monsoon tourist activity decreases and pollutants leach out. Therefore, one cannot rule out an increase in moss growth more rapidly during rains, which reduces the metal percentage in moss in proportion to biomass. 
Concentration of zinc in moss was found significantly higher than that of the control site (Table 1). Calculating the average of five consecutive years (2003-2007), Zn concentration was found higher towards west at $0.5 \mathrm{~km}$ during all three seasons i.e. summer, monsoon and winter (Table 1). However, $\mathrm{Zn}$ concentration is much higher towards south at $1 \mathrm{~km}$ and west at $0.5 \mathrm{~km}$ during all the five consecutive years (Figures 1-5). These areas are highly influenced by the concentration of $\mathrm{Zn}$ because people of this area are engaged in agricultural practices. $\mathrm{Zn}$ at a lower concentration promotes the growth of plants and is therefore used in fertilizers. On the contrary, it is also used as fungicide and pesticide in agricultural practices (Otvos et al., 2003). $\mathrm{Zn}$ is also concentrated in the areas of high traffic density (Gerdol et al., 2000) and is a major constituent of roads themselves, as asphalt pavement contains cobalt, nickel, and zinc (Sardans \& Penuelas, 2005), thus, motorization and movement of light and heavy trucks used for transportation may explain for the high zinc accumulation by the moss samples.

A high $\mathrm{Pb}$ concentration is, however, considerably nearly 1.5 times higher than that measured at the control site (Table 1). On the other hand, the $\mathrm{Pb}$ concentration was also found maximal towards south at the distance of $1 \mathrm{~km}$ and west at 0.5 $\mathrm{km}$ (Figures 1-5). This suggests that there is a significant $\mathrm{Pb}$ pollutant and probably vehicular emissions and leaded petrol are undoubtedly the reasons as suggested by Westerlund 2001, Adachi \&. Tainosho 2004, Vidovic et al. 2005. The $\mathrm{Pb}$ deposition values are thus positively related to the traffic and population density, and it further supports that local sources of $\mathrm{Pb}$ deposition are prevalent. Findings are in agreement with Chen et al. 1999, and also that $\mathrm{Pb}$ does not biodegrade, it remains in dust, soil and sediments, and accumulates, when more lead is released into the environment.

Results concerning $\mathrm{Cu}$ are strongly influenced by the extreme copper concentration at the same sites as that of $\mathrm{Zn}$ and $\mathrm{Pb}$, i.e. south at the distance of $1 \mathrm{~km}$ and west nearly at $0.5 \mathrm{~km}$ (Figures 1-5). These transplants are situated in proximity of the road where vehicular traffic is very heavy; therefore the motor driven transport is one of the suspected causes of $\mathrm{Cu}$ contamination. High percentage of copper can also be derived from engine wear (Pearson et al., 2000; Saxena et al., 2013), discharge scrap of domestic laundry waste, kerosene oil, automobile exhaust (Loppi \&Bonini, 2000) and integral part of fungicides practices in agriculture. Use of $\mathrm{CuSO}_{4}$ mixed kerosene could also be an important source of $\mathrm{Cu}$. This result is in agreement with the findings of Lopez et al. 1997, who also reported a similar rise in $\mathrm{Cu}$ level in inhabited areas.

Cd level was found low in comparison with other metal when it was measured in moss samples harvested from north at the distance of $1 \mathrm{~km}$ (Figures 1-5). It shows the biggest dissimilarity to other metals, which suggests the probability that it originates from independent sources. Among this municipal refuse, serapes are most suspected (Scharova \& Suchara, 1998; Grodzinska \& SzarekLukaszewska, 2001). Use of polyethene, domestic waste, sewage sludge, plastic pipes, and metal utensils is perhaps also responsible for the $\mathrm{Cd}$ contamination. It has also been reported from typical emission from fossil fuel combustion in automotive engines, while it is used in rubberized tires and occurs in wearing of tires. High concentration of $\mathrm{Cd}$ in moss in rural sites may be from agricultural land due to its use in phosphate fertilizers (Asthana \& Asthana, 2005). The outbreak of $\mathrm{Cd}$ in urban sites could be due to its use in paints and enamels containing cadmium compounds and in manufacturing of plastic bags, which are thoughtlessly widespread and used by people for storage of grocery items.

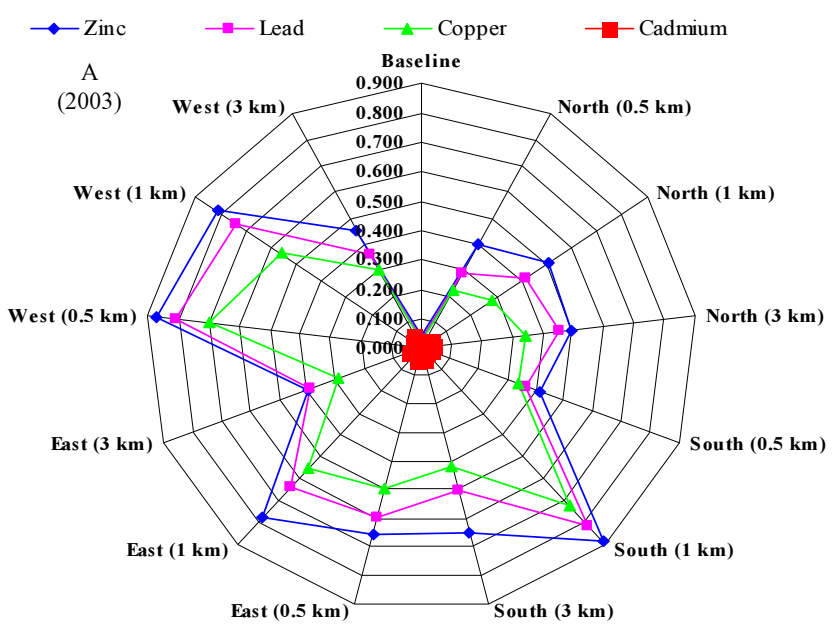

Fig. 1. Annual average metal load $\left(\mathrm{mg} \mathrm{g}^{-1} \mathrm{DW}\right)$ at different sites of Mussoorie City 2003 


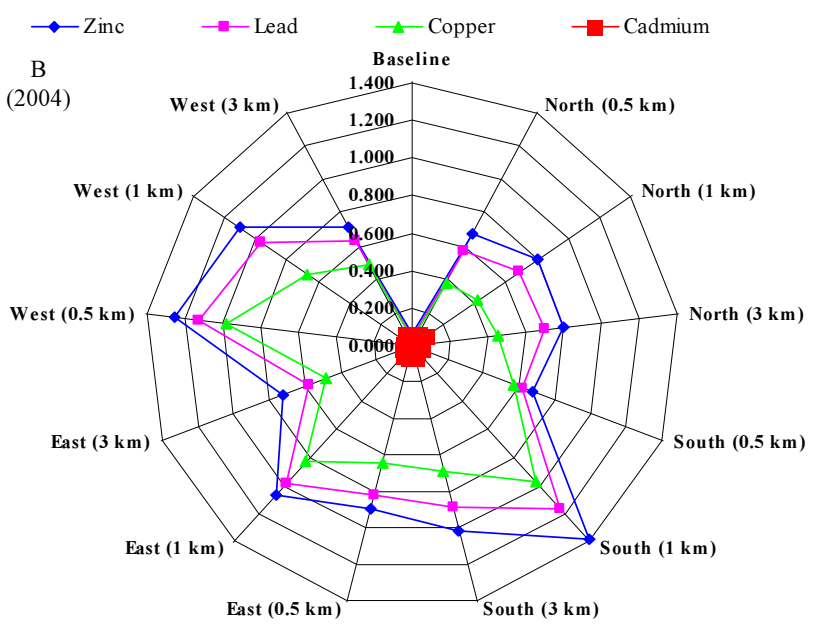

Fig. 2. Annual average metal load $\left(m g g^{-1} \mathrm{DW}\right)$ at different sites of Mussoorie City 2004

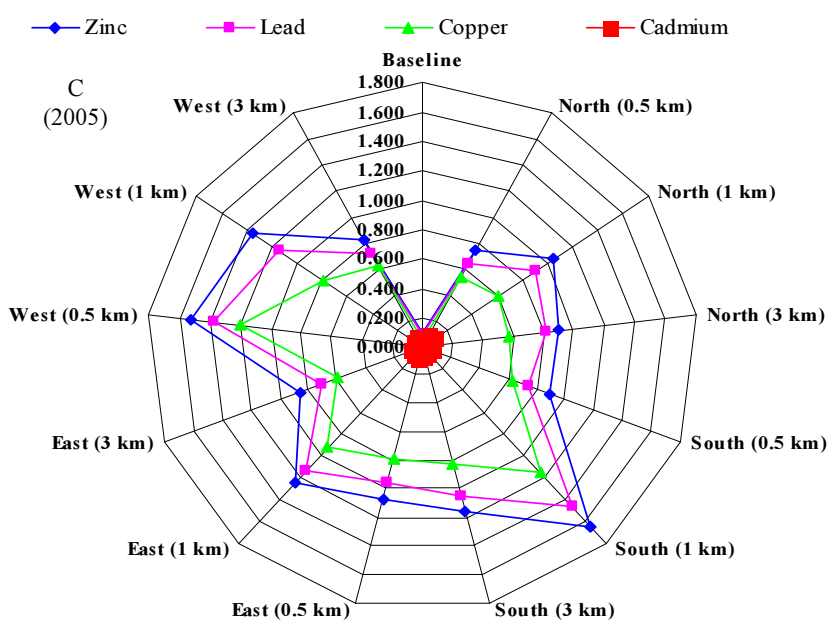

Fig. 3. Annual average metal load $\left(\mathrm{mg} \mathrm{g}^{-1} \mathrm{DW}\right)$ at different sites of Mussoorie City 2005

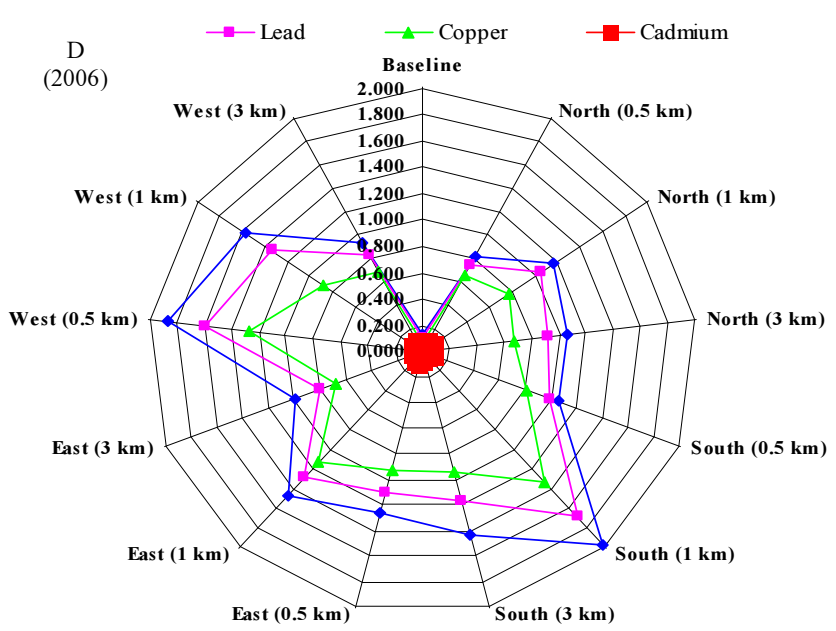

Fig. 4. Annual average metal load $\left(m g g^{-1} \mathrm{DW}\right)$ at different sites of Mussoorie City 2006 


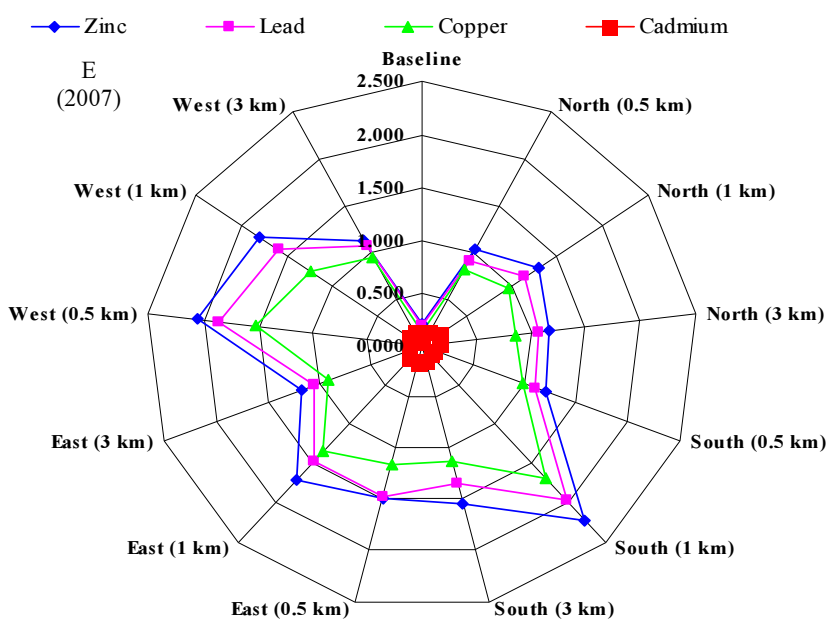

Fig. 5. Annual average metal load $\left(m g g^{-1} \mathrm{DW}\right)$ at different sites of Mussoorie City 2007 
Table 1. Average data of four metals ( $\mathrm{mg} \mathrm{g}^{-1} \mathrm{DW}$ ) during five consecutive years (2003 to 2007) in Barbula constricta at different transplant sites in Mussoorie city

\begin{tabular}{|c|c|c|c|c|c|c|c|c|c|c|c|c|}
\hline \multirow{2}{*}{$\begin{array}{l}\text { Sampling } \\
\text { Sites }\end{array}$} & \multicolumn{4}{|c|}{ Summer } & \multicolumn{4}{|c|}{ Monsoon } & \multicolumn{4}{|c|}{ Winter } \\
\hline & Zinc & Lead & Copper & Cadmium & Zinc & Lead & Copper & Cadmium & Zinc & Lead & Copper & Cadmium \\
\hline Baseline & $\begin{array}{c}0.224^{\mathrm{g}} \\
\pm 0.120\end{array}$ & $\begin{array}{r}0.205^{\mathrm{h}} \\
\pm 0.149\end{array}$ & $\begin{array}{r}0.117^{\mathrm{h}} \\
\pm 0.053\end{array}$ & $0.018^{\mathrm{c}} \pm 0.013$ & $\begin{array}{c}0.034^{\mathrm{g}} \\
\pm 0.023\end{array}$ & $\begin{array}{r}0.019^{\mathrm{f}} \\
\pm 0.017\end{array}$ & $\begin{array}{r}0.026^{\mathrm{f}} \\
\pm 0.035\end{array}$ & $\begin{array}{r}0.010^{\mathrm{d}} \\
\pm 0.005\end{array}$ & $\begin{array}{c}0.070^{\mathrm{h}} \\
\pm 0.066\end{array}$ & $\begin{array}{r}0.040^{\mathrm{h}} \\
\pm 0.028\end{array}$ & $\begin{array}{r}0.039^{\mathrm{g}} \\
\pm 0.046\end{array}$ & $0.010^{\mathrm{d}} \pm 0.008$ \\
\hline North $(0.5 \mathrm{~km})$ & $\begin{array}{c}0.817^{\mathrm{f}} \\
\pm 0.259\end{array}$ & $\begin{array}{r}0.698^{\mathrm{g}} \\
\pm 0.260\end{array}$ & $\begin{array}{r}0.633^{\mathrm{g}} \\
\pm 0.252\end{array}$ & $\begin{array}{l}0.138^{\mathrm{ab}} \\
\pm 0.069\end{array}$ & $\begin{array}{c}0.645^{\mathrm{f}} \\
\pm 0.207\end{array}$ & $\begin{array}{c}0.544^{\mathrm{e}} \\
\pm 0.201\end{array}$ & $\begin{array}{c}0.398^{\mathrm{e}} \\
\pm 0.196\end{array}$ & $\begin{array}{l}0.054^{\mathrm{ab}} \\
\pm 0.029\end{array}$ & $\begin{array}{l}0.722^{\mathrm{g}} \\
\pm 0.215\end{array}$ & $\begin{array}{c}0.648^{\mathrm{g}} \\
\pm 0.028\end{array}$ & $\begin{array}{c}0.531^{\mathrm{f}} \\
\pm 0.262\end{array}$ & $\begin{array}{r}0.076^{\mathrm{abc}} \\
\pm 0.036\end{array}$ \\
\hline North $(1.0 \mathrm{~km})$ & $\begin{array}{l}1.101^{\text {def }} \\
\pm 0.351\end{array}$ & $\begin{array}{l}0.927^{\text {ef }} \\
\pm 0.314\end{array}$ & $\begin{array}{r}0.751^{\mathrm{efg}} \\
\pm 0.336\end{array}$ & $0.159^{\mathrm{a}} \pm 0.083$ & $\begin{array}{l}0.822^{\mathrm{def}} \\
\pm 0.274\end{array}$ & $\begin{array}{c}0.707^{\text {cde }} \\
\pm 0.270\end{array}$ & $\begin{array}{l}0.449^{\mathrm{de}} \\
\pm 0.199\end{array}$ & $0.071^{\mathrm{a}} \pm 0.030$ & $\begin{array}{c}0.958^{\text {defg }} \\
\pm 0.317\end{array}$ & $\begin{array}{r}0.878^{\text {defg }} \\
\pm 0.305\end{array}$ & $\begin{array}{c}0.624^{\text {def }} \\
\pm 0.275\end{array}$ & $\begin{array}{r}0.094^{\mathrm{a}} \\
\pm 0.053\end{array}$ \\
\hline North $(3.0 \mathrm{~km})$ & $\begin{array}{l}1.003^{\mathrm{f}} \\
\pm 0.275\end{array}$ & $\begin{array}{r}0.909^{\mathrm{efg}} \\
\pm 0.246\end{array}$ & $\begin{array}{r}0.713^{\text {efg }} \\
\pm 0.241\end{array}$ & $\begin{array}{l}0.132^{\mathrm{ab}} \\
\pm 0.052\end{array}$ & $\begin{array}{l}0.763^{\text {ef }} \\
\pm 0.256\end{array}$ & $\begin{array}{r}0.705^{\text {cde }} \\
\pm 0.230\end{array}$ & $\begin{array}{l}0.435^{\text {de }} \\
\pm 0.151\end{array}$ & $\begin{array}{l}0.050^{\mathrm{bc}} \\
\pm 0.036\end{array}$ & $\begin{array}{l}0.896^{\mathrm{efg}} \\
\pm 0.264\end{array}$ & $\begin{array}{c}0.763^{\text {efg }} \\
\pm 0.227\end{array}$ & $\begin{array}{r}0.570^{\mathrm{f}} \\
\pm 0.197\end{array}$ & $\begin{array}{r}0.073^{\text {abc }} \\
\pm 0.055\end{array}$ \\
\hline South $(0.5 \mathrm{~km})$ & $\begin{array}{c}0.993^{\mathrm{f}} \\
\pm 0.349\end{array}$ & $\begin{array}{r}0.886^{\mathrm{efg}} \\
\pm 0.295\end{array}$ & $\begin{array}{r}0.760^{\mathrm{efg}} \\
\pm 0.244\end{array}$ & $\begin{array}{l}0.117^{\text {ab }} \\
\pm 0.057\end{array}$ & $\begin{array}{c}0.705^{\mathrm{f}} \\
\pm 0.288\end{array}$ & $\begin{array}{l}0.647^{\mathrm{de}} \\
\pm 0.278\end{array}$ & $\begin{array}{c}0.572^{\text {bcd }} \\
\pm 0.236\end{array}$ & $\begin{array}{l}0.045^{\mathrm{bc}} \\
\pm 0.028\end{array}$ & $\begin{array}{l}0.838^{\mathrm{fg}} \\
\pm 0.293\end{array}$ & $\begin{array}{r}0.749^{\mathrm{efg}} \\
\pm 0.306\end{array}$ & $\begin{array}{c}0.660^{\text {cdef }} \\
\pm 0.251\end{array}$ & $\begin{array}{l}0.059^{\text {bc }} \\
\pm 0.028\end{array}$ \\
\hline South $(1.0 \mathrm{~km})$ & $\begin{array}{l}1.858^{\mathrm{a}} \\
\pm 0.597\end{array}$ & $\begin{array}{r}1.599^{\mathrm{a}} \\
\pm 0.482\end{array}$ & $\begin{array}{r}1.418^{\mathrm{a}} \\
\pm 0.426\end{array}$ & $\begin{array}{r}0.104^{b} \\
\pm 0.058\end{array}$ & $\begin{array}{l}1.407^{\mathrm{a}} \\
\pm 0.451\end{array}$ & $\begin{array}{r}1.255^{\mathrm{a}} \\
\pm 0.427\end{array}$ & $\begin{array}{r}0.934^{\mathrm{a}} \\
\pm 0.308\end{array}$ & $0.033^{\mathrm{c}} \pm 0.023$ & $\begin{array}{r}1.585^{\mathrm{a}} \\
\pm 0.510\end{array}$ & $\begin{array}{r}1.394^{\mathrm{a}} \\
\pm 0.437\end{array}$ & $\begin{array}{c}1.154^{\mathrm{a}} \\
\pm 0.365\end{array}$ & $\begin{array}{l}0.050^{\mathrm{bc}} \\
\pm 0.031\end{array}$ \\
\hline South $(3.0 \mathrm{~km})$ & $\begin{array}{l}1.322^{\text {cde }} \\
\pm 0.413\end{array}$ & $\begin{array}{l}1.087^{\text {de }} \\
\pm 0.357\end{array}$ & $\begin{array}{r}0.924^{\text {def }} \\
\pm 0.302\end{array}$ & $\begin{array}{l}0.126^{\mathrm{ab}} \\
\pm 0.042\end{array}$ & $\begin{array}{l}1.009^{\mathrm{cd}} \\
\pm 0.343\end{array}$ & $\begin{array}{l}0.892^{\text {cd }} \\
\pm 0.287\end{array}$ & $\begin{array}{l}0.699^{\mathrm{bc}} \\
\pm 0.230\end{array}$ & $\begin{array}{l}0.042^{\mathrm{bc}} \\
\pm 0.030\end{array}$ & $\begin{array}{l}1.129^{\text {cde }} \\
\pm 0.307\end{array}$ & $\begin{array}{r}0.981^{\text {cde }} \\
\pm 0.312\end{array}$ & $\begin{array}{r}0.772^{\text {bcde }} \\
\pm 0.279\end{array}$ & $\begin{array}{r}0.066^{\text {abc }} \\
\pm 0.040\end{array}$ \\
\hline East $(0.5 \mathrm{~km})$ & $\begin{array}{l}1.361^{\mathrm{cd}} \\
\pm 0.345\end{array}$ & $\begin{array}{l}1.237^{\mathrm{cd}} \\
\pm 0.305\end{array}$ & $\begin{array}{l}1.027^{\mathrm{cd}} \\
\pm 0.230\end{array}$ & $0.157^{\mathrm{a}} \pm 0.054$ & $\begin{array}{l}0.810^{\text {def }} \\
\pm 0.275\end{array}$ & $\begin{array}{r}0.782^{\text {cde }} \\
\pm 0.362\end{array}$ & $\begin{array}{r}0.553^{\text {cde }} \\
\pm 0.257\end{array}$ & $\begin{array}{l}0.042^{\mathrm{bc}} \\
\pm 0.034\end{array}$ & $\begin{array}{l}1.046^{\mathrm{def}} \\
\pm 0.347\end{array}$ & $\begin{array}{r}0.946^{\text {cdef }} \\
\pm 0.338\end{array}$ & $\begin{array}{l}0.819^{\mathrm{bc}} \\
\pm 0.288\end{array}$ & $\begin{array}{r}0.067^{\mathrm{abc}} \\
\pm 0.036\end{array}$ \\
\hline East $(1.0 \mathrm{~km})$ & $\begin{array}{l}1.532^{\mathrm{bc}} \\
\pm 0.426\end{array}$ & $\begin{array}{l}1.349^{\mathrm{bc}} \\
\pm 0.335\end{array}$ & $\begin{array}{l}1.173^{\mathrm{bc}} \\
\pm 0.326\end{array}$ & $\begin{array}{l}0.134^{\mathrm{ab}} \\
\pm 0.073\end{array}$ & $\begin{array}{l}1.000^{\text {cde }} \\
\pm 0.328\end{array}$ & $\begin{array}{l}0.872^{\mathrm{cd}} \\
\pm 0.293\end{array}$ & $\begin{array}{r}0.732^{\mathrm{b}} \\
\pm 0.304\end{array}$ & $\begin{array}{r}0.051^{\mathrm{abc}} \\
\pm 0.030\end{array}$ & $\begin{array}{l}1.206^{\mathrm{cd}} \\
\pm 0.325\end{array}$ & $\begin{array}{l}1.068^{\mathrm{cd}} \\
\pm 0.313\end{array}$ & $\begin{array}{l}0.962^{\mathrm{ab}} \\
\pm 0.289\end{array}$ & $\begin{array}{r}0.077^{\text {abc }} \\
\pm 0.048\end{array}$ \\
\hline East $(3.0 \mathrm{~km})$ & $\begin{array}{l}1.050^{\text {ef }} \\
\pm 0.359\end{array}$ & $\begin{array}{r}0.869^{\mathrm{efg}} \\
\pm 0.296\end{array}$ & $\begin{array}{r}0.746^{\text {efg }} \\
\pm 0.266\end{array}$ & $\begin{array}{l}0.136^{\mathrm{ab}} \\
\pm 0.047\end{array}$ & $\begin{array}{r}0.631^{\mathrm{f}} \\
\pm 0.252\end{array}$ & $\begin{array}{r}0.554^{\mathrm{e}} \\
\pm 0.213\end{array}$ & $\begin{array}{l}0.441^{\text {de }} \\
\pm 0.202\end{array}$ & $\begin{array}{l}0.035^{\mathrm{bc}} \\
\pm 0.017\end{array}$ & $\begin{array}{l}0.791^{\mathrm{fg}} \\
\pm 0.272\end{array}$ & $\begin{array}{r}0.672^{\mathrm{g}} \\
\pm 0.249\end{array}$ & $\begin{array}{l}0.581^{\text {ef }} \\
\pm 0.235\end{array}$ & $\begin{array}{l}0.054^{\mathrm{bc}} \\
\pm 0.037\end{array}$ \\
\hline West $(0.5 \mathrm{~km})$ & $\begin{array}{l}1.759^{\mathrm{ab}} \\
\pm 0.549\end{array}$ & $\begin{array}{l}1.540^{\mathrm{ab}} \\
\pm 0.438\end{array}$ & $\begin{array}{l}1.324^{\mathrm{ab}} \\
\pm 0.357\end{array}$ & $\begin{array}{r}0.105^{\mathrm{b}} \\
\pm 0.054\end{array}$ & $\begin{array}{l}1.298^{\mathrm{ab}} \\
\pm 0.408\end{array}$ & $\begin{array}{l}1.183^{\mathrm{ab}} \\
\pm 0.384\end{array}$ & $\begin{array}{c}0.969^{\mathrm{a}} \\
\pm 0.276\end{array}$ & $\begin{array}{l}0.037^{\mathrm{bc}} \\
\pm 0.022\end{array}$ & $\begin{array}{l}1.472^{\mathrm{ab}} \\
\pm 0.466\end{array}$ & $\begin{array}{l}1.327^{\mathrm{ab}} \\
\pm 0.405\end{array}$ & $\begin{array}{r}1.109^{\mathrm{a}} \\
\pm 0.306\end{array}$ & $0.048^{\mathrm{c}} \pm 0.024$ \\
\hline West $(1.0 \mathrm{~km})$ & $\begin{array}{l}1.551^{\mathrm{bc}} \\
\pm 0.425\end{array}$ & $\begin{array}{l}1.370^{\mathrm{bc}} \\
\pm 0.358\end{array}$ & $\begin{array}{r}0.960^{\text {cde }} \\
\pm 0.330\end{array}$ & $\begin{array}{l}0.117^{\mathrm{ab}} \\
\pm 0.052\end{array}$ & $\begin{array}{l}1.094^{\mathrm{bc}} \\
\pm 0.359\end{array}$ & $\begin{array}{l}0.946^{\mathrm{bc}} \\
\pm 0.298\end{array}$ & $\begin{array}{l}0.694^{\mathrm{bc}} \\
\pm 0.188\end{array}$ & $\begin{array}{l}0.042^{\mathrm{bc}} \\
\pm 0.026\end{array}$ & $\begin{array}{l}1.320^{\mathrm{bc}} \\
\pm 0.381\end{array}$ & $\begin{array}{l}1.138^{\mathrm{bc}} \\
\pm 0.338\end{array}$ & $\begin{array}{r}0.813^{\text {bcd }} \\
\pm 0.259\end{array}$ & $\begin{array}{l}0.058^{\mathrm{bc}} \\
\pm 0.033\end{array}$ \\
\hline West $(3.0 \mathrm{~km})$ & $\begin{array}{l}0.923^{\mathrm{f}} \\
\pm 0.271\end{array}$ & $\begin{array}{l}0.839^{\text {fg }} \\
\pm 0.269\end{array}$ & $\begin{array}{r}0.778^{\text {efg }} \\
\pm 0.255\end{array}$ & $\begin{array}{l}0.140^{\mathrm{ab}} \\
\pm 0.045\end{array}$ & $\begin{array}{c}0.695^{\mathrm{f}} \\
\pm 0.217\end{array}$ & $\begin{array}{r}0.616^{\mathrm{e}} \\
\pm 0.258\end{array}$ & $\begin{array}{l}0.466^{\text {de }} \\
\pm 0.212\end{array}$ & $\begin{array}{l}0.050^{\mathrm{bc}} \\
\pm 0.028\end{array}$ & $\begin{array}{l}0.793^{\mathrm{fg}} \\
\pm 0.268\end{array}$ & $\begin{array}{l}0.705^{\mathrm{fg}} \\
\pm 0.266\end{array}$ & $\begin{array}{l}0.579^{\text {ef }} \\
\pm 0.266\end{array}$ & $\begin{array}{l}0.078^{\text {ab }} \\
\pm 0.041\end{array}$ \\
\hline
\end{tabular}

Values are represented as mean \pm SD

*Levels not connected by the same letters are significantly different 


\section{Conclusions}

Over all, the results suggest that the potential source of metals is automobiles as a result of high tourist activity which depicts an alarming pollution level in proximity to the city. Besides, climatic factors could also modify the effects of metals and should be taken into consideration in bio-monitoring surveys. The present work encourages the use of Barbula constricta as bio-monitors using applying a biomapping approach that has proved to be a perfect tool for assessment of atmospheric loads. The research has highlighted the seasonal and annual metal pollution and the extent of contamination in the study area. It also has examined the distribution pattern of taken metals. In future the study will be extended in adjoining areas after calibration of the moss that can be inducted as an alternative in bio-monitoring, if Barbula sp. were not available. The potential benefit of a bio-monitoring program is to identify geographical locations where people have much different burdens than the general population. It also offers a potential to be a powerful tool in the studies that attempt to examine the relationship between exposure to hazardous substances and a subsequent risk for diseases. Bio-monitoring data can also be used to evaluate the effectiveness of specific policies that attempt to reduce or ban particular substances responsible for causing pollution in the area.

\section{Acknowledgements}

The present study is part of the major project funded by the Ministry of Environment and Forest, Govt. of India. Authors like to pay their gratitude to the Department of Biotechnology, the Ministry of Science and Technology for funding Atomic Absorption Spectrophotometer. We also like to acknowledge the help of the Meteorological Service Station, Dehradun for providing the meteorological data used in this survey.

\section{References}

Markert, B.A., Breure, A.M., Zecmeister, H.G. 2003. Bioindicators/biomonitors (Principles, Assessment, Concepts). Elsevier, Amsterdam. www.ecotox.at/publikationen.html.

Genoni, P., Parco, V., Santagostino, A. Metal biomonitoring with mosses in the surrounding of an oil fired power plant in Italy, Chemosphere. 2000. Vol. 41. pp. 729733. ISSN: 0045-6535.

Carballeira, A., Fernandez, J.A. Bioconcentration of metals in the moss Scleropodium purum in the area surrounding a power plant. A geotopographical predictive model for mercury. Chemosphere. 2002. Vol. 47. pp. 10411048. ISSN: 0045-6535.

Culicov, O.A., Frontasyeva, M.V., Steinnes, E., Okina, O.S., Santa, Zs., Todoran, R. Atmospheric deposition of heavy metals around the lead and copper-zinc smelters in Baia mare, Romania, studied by the moss biomonitoring technique, neutron activation analysis and flame atomic absorption spectrometry. Journal of
Radioanal. Nuclear Chemistry. 2002. Vol. 254, No. 4. pp. 109-115. ISSN: 0236-5731.

Ruhling, A., Tyler, G. An ecological approach to the lead problem. Botaniska Notiser. 1968. Vol. 122. pp. 248342. ISSN: 0006-8195.

Ruhling, A., Tyler, G. Heavy metal deposition in Scandinavia. Water, Air and Soil Pollution. 1973. Vol. 2. pp. 445-455. ISSN: 1567-7230.

Figueira, R., Sergio, C., Sousa, A.J., Distribution of trace metals in moss biomonitors and assessment of contamination sources in Portugal. Environmental Pollution. 2002. Vol. 118. pp. 153-163. ISSN: 0269-7491.

Aceto, M., Abolino, O., Conca, R., Malandrino, M., Mentasti, E., Sarzanini, C. The use of mosses as environmental pollution indicators. Chemosphere. 2003. Vol. 50. pp. 333-342. ISSN: 0045-6535.

Schilling, J.S., Lehman, M.E. Bioindication of atmospheric heavy metal deposition in the Southeastern US using the moss Thuidium delicatulum. Atmospheric Environment. 2002. Vol. 36. pp. 1611-1618. ISSN: 13522310.

Poikolainen, J., Kubin, E., Piispanen, J., Karhu, J. Atmospheric heavy metal deposition in Finland during 1985-2000 using mosses as bioindicators. The Science of the Total Environment. 2004. Vol. 318. pp. 171-185. ISSN: 0048-9697.

Saxena, D.K.., Singh, S., Srivastava, K. Metal precipitation in Garhwal hill area (India): Estimation based on native moss analysis. Aerosol and Air Quality Research. 2008. Vol. 8. No. 1. pp. 94-111. ISSN: 16808584.

Ceburnis, D., Valiulis, D. Investigation of absolute metal uptake efficiency from precipitation in moss. The Science of the Total Environment. 1999. Vol. 226 . No. 23. pp. 247-253. ISSN: 0048-9697.

Fernandez, J.A., Aboal, J.R., Carballeira, A. Use of native and transplanted mosses as complimentary techniques for biomonitoring mercury around an industrial facility. The Science of the Total Environment. 2000. Vol. 256. No. 2-3. pp. 51-156. ISSN: 0048-9697.

Couto, J.A., Aboal, J.R., Fernandez, J.A., Carballeira, A. A new method for testing the sensitivity of active biomonitoring: an example of its application to a terrestrial moss. Chemosphere. 2004. Vol. 57. No. 4 pp. 303-308. ISSN: 0045-6535.

Špirić, Z., Vučković, I., Stafilov, T., Kušan, V., Frontasyeva, M. Air Pollution Study in Croatia Using Moss Biomonitoring and ICP-AES and AAS Analytical Techniques. Archives of Environmental Contamination and Toxicology. 2013. Vol. 65. No. 1. pp. 33-46. ISSN: 00904341.

Saxena, D.K., Srivastava, K., Singh, S. Studies on Barbula species from Kumaon and Garhwal hills of Uttaranchal region (India). Proceeding of National Academy of Sciences. 2007. Vol. 77. No. 2. pp. 15-19. ISSN: 0369-8211.

Otvos, E., Pazmandi, T., Tuba, Z. First national survey of atmospheric heavy metal deposition Hungary by the analysis of mosses. The Science of the Total Environment. 2003. Vol. 309. pp. 151-160. ISSN: 00489697.

Gerdol, R., Bragazza, L., Marchesine, R., Alber, R., Bonetti, L., Lorenzoni, G., Achilli, M., Buffoni, A., De Marco, N., Franchi, M., Pison, S., Giaquinta, S., Palmieri, F., Spezzano, P. Monitoring of heavy metal deposition in Northern Italy by moss analysis. Environment Pollution, 2000. Vol. 108. pp. 201-208. ISSN: 0269-7491.

Sardans, J., Penuelas, J. Trace element accumulation in the moss Hypnum cupressiforme Hedw. and the trees Quercus ilex L., and Pinus halepensis Mill. In Catalonia. 
Chemosphere. 2005. Vol. 60. pp. 1293-1307. ISSN: 00456535 .

Westerlund, K.G. 2001. Metal emissions from Stockholm traffic-wear of brake linings. Reports from SLB. Analysis, 3.

Adachi, K., Tainosho, Y. Characterization of heavy metal particles embedded in tire dust. Environment International, 2004. Vol. 30. pp. 1009-1017. ISSN: 01604120.

Vidovic, M., Sadibasic, A., Cupic, S., Lausevic, M. $\mathrm{Cd}$ and $\mathrm{Pb}$ in atmospheric deposit, soil, wheat and milk. Environmental Research. 2005. Vol. 97. pp. 26-31. ISSN: 0013-9351.

Chen, G.H., Chen, M.Z., Di, R.J. Assessment of prospecting potentiality for superlarge continental volcanic rock-type uranium deposits in China. Chinese Journal of Geochemistry. 1999. Vol. 18. pp. 350-360. ISSN: 10009426.

Pearson, J., Wells, D. M., Seller, K. J., Bennett, A., Soares, A., Woodall, J., Ingroyile, M. J. Traffic exposure increase natural $15 \mathrm{~N}$ and heavy metal concentrations in mosses. New Phytology. 2000. Vol. 147. pp. 317-326. ISSN: $1469-8137$.

Saxena, D.K., Hooda, P., Singh, S., Srivastava, K., Kalaji, H.M., Gahtori, D. An Assessment of atmospheric metal deposition in Garhwal hills, India by moss Rhodobryum giganteum (Schwaegr.) Par. 2013. Geophytology. Vol. 43 No.1. pp. 17-28. ISSN: 0376-5561.

Loppi, S., Bonini, I. Lichens and mosses as biomonitors of trace elements in areas with thermal springs and fumarole activity (Mt. Amiata, Central Italy). Chemosphere. 2000. Vol. 41. pp. 1333-1336. ISSN: 00456535.

Lopez, J., Retuerto, R., Carballeira, A. D665/D665a index vs frequencies as indicators of bryophyte response to physicochemical gradients. Ecology, 1997. Vol. 78. No. 1. pp. 261-271. ISSN: 0012-9658.

Scharova, J. , Suchara, I. Atmospheric deposition levels of chosen elements in the Czech republic determined in the framework of the International Bryomonitoring Program 1995. The Science of the Total Environment 1998. Vol. 223. pp. 37-52. ISSN: 0048-9697.

Grodzinska, K., Szarek-Lukaszewska, G. Response of mosses to the heavy metal deposition in Poland - an overview. Environment Pollution. 2001. Vol. 114. pp. 443451. ISSN: 0269-7491.

Asthana, D.K., Asthana, M. 2005. Environment: Problems and Solutions. New Delhi: S. Chand and Company Ltd., Ramnagar. pp. 166-181.

Dr. Kajal Srivastava - Department of Biological Sciences, CBSH, G.B. Pant University of Agriculture \& Technology, Pantnagar, UA, India E-mail: Kajals101@rediffmail.com

Dr. Shivom Singh - Department of Environmental Sciences and Technology, ITM University, Gwalior, M.P. India

E-mail: shivom101@rediffmail.com

Dr. Dinesh Kumar Saxena - Department of Botany, Bareilly College, Bareilly, U. P. India E-mail: dineshbotany@gmail.com 


\title{
Metalų nusėdimo samanose Barbula constricta J. Linn stebėsena. Mussoorie kalvos Indijoje
}

\author{
Kajal Srivastava ${ }^{1}$, Shivom Singh ${ }^{2}$ ir Dinesh K. Saxena ${ }^{3}$ \\ 'Žemès ükio ir technologiju G. B. Pant universitetas, Biologiniu mokslų katedra, CBSH \\ ${ }^{2}$ ITM universitetas, Aplinkos moksly ir technologiju katedra \\ ${ }^{3}$ Bareilly kolegija, Botanikos katedra
}

(gauta 2013 m. spalio mèn.; atiduota spaudai 2014 m. kovo mèn.)

Aktyviam biomonitoringui atlikti buvo naudojamos Samanos Barbula constricta J. Linn. Atliktas atmosferinių metalų ( $\mathrm{Zn}, \mathrm{Pb}, \mathrm{Cu}$ ir $\mathrm{Cd}$ ) išsedimo ir sezoniškumo įvertinimas Mussoorie mieste ir jo apylinkèse. Samanu transplantacijos buvo veikiamos keturis mènesius - kiekvienas mẻnuo buvo pasirinktas dell reprezentacinio sezoniškumo vaizdavimo, t. y. žiemos, vasaros ir musoninio sezonu. Duomenys buvo renkami 0,5, 1,0 ir 3,0 km atstumais. Laikotarpis 2003-2007 $\mathrm{m}$.

Kiekvieno sezono pabaigoje surinktuose samanų mėginiuose buvo aptiktos aukštesnio lygio $\mathrm{Zn}, \mathrm{Pb}$ ir $\mathrm{Cu}$ koncentracijos. Metalų vertès skirtinguose atstumuose nuo miesto centro buvo didesnès nei kontroliniuose pavyzdžiuose. Surinkti sezoniniai ir metiniai samanų mėginių duomenys buvo labai panašūs. Didžiausios metalų koncentracijų vertès buvo vasaros sezonu iškart po žiemos ir mažiausios - musono sezono metu. Buvo nustatyta, kad metalu kiekiai per pastaruosius penkerius metus didejo, o taip galèjo atsitikti dèl mėginių èmimo teritorijoje vykusio spartaus ekonominio augimo ir daug kartų padidejusio turizmo. Atliekant samanų tyrimus buvo tiriamos metalų kitimo tendencijos tiek erdveje, tiek laike. Buvo ịrodytas samanu $B$. constricta J. Linn. tinkamumas tirti kaip patikima ir rekomenduojama biologinėms kartografavimo programoms biologinès stebėsenos priemonè. Iki šiol buvo atlikta labai mažai metalų koncentracijos tyrimų samanose, detaliau išanalizuota tik nedidelè duomenų dalis. Be to, šio tyrimo rezultatai yra svarūs ir neịkainojami politikams - sprendimu prièmejjams, rengiant ivairias švelninimo strategijas. 